\title{
EKSPEKTASI PEMEGANG POLIS GENERASI Y DAN PERSEPSI DARI PERUSAHAAN ASURANSI KESEHATAN DI JABODETABEK
}

\author{
Ayu Diaztari ${ }^{1}$, Bima Ardi $^{2}$, Derry Adhi ${ }^{3}$, \\ Wenny Priscillia ${ }^{4}$, Yuricho Billy $^{5}$ \\ ${ }^{1}$ ayudiaztari@gmail.com \\ ${ }^{2}$ bima4ardi@gmail.com \\ 33erryadhi@gmail.com \\ 4priscilla.gwen@yahoo.co.id \\ 5yurichobilly@gmail.com
}

Program MM Sekolah Bisnis dan Ekonomi Universitas Prasetiya Mulya

\begin{abstract}
This research aims to know if there is any gap between expectations of the generation $Y$ policy holders in Jabodetabek and their perceptions towards products and services from companies that the policy holders received. This research used SERVQUAL model toward Reliability, Assurance, Tangibility, Empathy, and Responsiveness. Subject population of this study is the $Y$ generation who has health insurance policy. The sample are 130 person (92 male, 46 female). Researcher used SERVQUAL scores and also statistical description for analysis. The result found a gap exists between the expectations and perceptions from policyolders, where the expectations are higher than the perceptions.
\end{abstract}

Keywords; health insurance, consumers' expectation, consumers' perception, SERVQUAL model.

\begin{abstract}
ABSTRAK
Penelitian ini memiliki tujuan untuk mengetahui apakah kesenjangan dapat ditemukan antara ekspektasi pemegang polis generasi $Y$ di Jabodetabek dan persepsi terhadap produk dan layanan perusahaan yang telah diterima oleh pemegang polis. Penelitian ini menggunakan model SERVQUAL terhadap Reliability, Assurance, Tangibility, Empathy, dan Responsiveness. Populasinya adalah generasi $\mathrm{Y}$ yang memiliki polis asuransi kesehatan yang berada di Jabodetabek. Dengan sampe berjumlah 138 orang (92 laki-laki dan 46 perempuan). Analisis data menggunakan statistik deskriptif dan model SERVQUAL. Hasil penelitian menemukan gap antara ekspetasi dan persepsi bagi pemegang polis di mana ekspetasi lebih tinggi dari pada persepsi.
\end{abstract}

Kata kunci: asuransi kesehatan, ekspektasi pemegang polis, persepsi pemegang polis, model SERVQUAL

\section{PENDAHULUAN}

Asuransi kesehatan merupakan salah satu jenis produk asuransi. Asuransi kesehatan secara khusus menjamin biaya kesehatan atau perawatan para pemegang polis jika mereka 
jatuh sakit atau mengalami kecelakaan (Wikipedia, 2000). Saat ini asuransi dinilai memiliki peran yang sangat penting di dalam kehidupan masyarakat maupun korporat. Produk asuransi diselenggarakan baik oleh perusahaan asuransi sosial, perusahaan asuransi jiwa, maupun juga perusahaan asuransi umum.

Hingga saat ini, pertumbuhan asuransi di Indonesia banyak terhambat dengan adanya beberapa masalah yang ada. Dimana adanya banyak kasus asuransi kesehatan yang masih menjadi permasalahan, baik dari sisi perusahaan dan dari sisi anggota dari asuransi tersebut. Permasalahan dalam industri asuransi saat ini yaitu perihal permodalan yang tidak mencukupi dan klaim yang bermasalah.

Terhambatnya pertumbuhan dari perusahaan asuransi kesehatan di Indonesia khususnya di Jabodetabek dipengaruhi oleh banyak faktor. Dimana hingga saat ini berdasarkan riset Otoritas Jasa Keuangan (OJK), tingkat utilitas asuransi di Indonesia baru mencapai 11,81\%. Padahal potensi pasar asuransi di Indonesia mencapai 88,19\%. Dan generasi $Y$ merupakan pemegang demografi terbesar di Indonesia. Sehingga dengan adanya hal itu, generasi $Y$ merupakan pasar yang sangat menarik bagi perusahaan asuransi kesehatan.

Hal lain yang mempengaruhi pertumbuhan dari perusahaan asuransi adalah adanya persaingan antar perusahaan asuransi kesehatan yang semakin ketat. Semakin ketat kompetisi pada industry asuransi kesehatan, semakin banyak alternative yang dimiliki oleh pemegang polis. Hal ini mencakup alternatif produk, harga dan kualitas yang bervariasi, sehingga pemegang polis akan selalu mencari nilai yang dianggap paling menguntungkan dari beberapa produk (Kotler, 2005).

Para perusahaan asuransi kesehatan terus berusaha untuk memberikan pelayanan yang sebaik mungkin kepada pada pemegang polis mereka agar mereka dapat tetap bertahan dan tumbuh berkembang. Oleh karena itu perusahaan asuransi kesehatan harus dapat terus berkomunikasi dengan baik dengan para pemegang polis mereka agar perusahaan asuransi kesehatan tersebut dapat lebih memahami apa yang diinginkan oleh pemegang polis. Selain itu perusahaan asuransi kesehatan juga dapat mengevaluasi apakah semua nila-nilai dari pelayanan mereka sudah tersampaikan dengan baik bagi pemegang polis. Sehingga dengan adanya hal tersebut, perusahaan asuransi kesehatan dapat terus-menerus melakukan perbaikan dalam pemberian layanan dengan kualitas yang baik yang berdampak pada kepuasan pemegang polis.

Kepuasan pemegang polis merupakan salah satu kunci utama dalam menciptakan loyalitas pemegang polis. Banyak manfaat yang diterima oleh perusahaan dengan tercapainya tingkat kepuasan pemegang polis yang tinggi, yakni selain dapat meningkatkan loyalitas pemegang polis tapi juga dapat mencegah terjadinya perputaran pemegang polis, mengurangi sensitivitas pemegang polis terhadap harga, mengurangi biaya kegagalan pemasaran, mengurangi biaya operasi yang diakibatkan oleh meningkatnya jumlah pemegang polis, meningkatkan efektivitas iklan, dan meningkatkan reputasi bisnis (Fornell, 1992). Keputusan perusahaan melakukan tindakan perbaikan pelayanan yang sistematis merupakan payung yang menentukan dalam menindaklanjuti komplain konsumen dari suatu kegagalan sehingga pada akhirnya mampu mengikat loyalitasi konsumen (Elu, 2005).

Adanya asimetris informasi antara pemegang polis sebagai pemegang polis dan perusahaan asuransi kesehatan itu sendiri menjadikan pertumbuhan dari perusahaan asuransi 
kesehatan semakin sulit. Dan dengan adanya riset ini kita dapat mengetahui bagaimana kondisi pelayanan dari perusahaan asuransi kesehatan di Jabodetabek, apakah sudah sesuai atau tidak dengan ekspektasi yang ada dari sisi pemegang polis.

\section{Tujuan Penelitian}

Seperti yang sudah dijelaskan sebelumnya, dapat dikatakan bahwa kesenjangan dalam pelayanan asuransi menjadi isu yang sangat penting, penilaian atas apa yang di dapat / terima oleh pemegang polis menunjukan bahwa pelayanan tersebut memang ditunggu / diharapkan oleh pemegang polis. Pada akhirnya hal ini akan berdampak langsung pada kepuasan dan loyalitas pemegang polis. Itulah sebabnya penelitian ini berusaha untuk mengenali kualitas layanan yang ada di perusahaan asuransi kesehatan kesehatan di Jabodetabek dan menawarkan saran untuk menyelesaikanya. Sehubungan dengan informasi yang diberikan di atas untuk penelitian ini, tujuan yang sudah ditetapkan dalam penelitian ini;

1. Untuk mengetahui kualitas layanan pada perusahaan asuransi kesehatan di Jabodetabek.

2. Untuk mengidentifikasi ekspektasi pemegang polis dan persepsi kualitas layanan yang telah diberikan oleh perusahaan asuransi kesehatan di Jabodetabek.

\section{Hipotesis penelitian:}

Berikut adalah hipotesis peneliti terkait tujuan dari penelitian ini:

Adanya gap kualitas layanan dalam layanan asuransi kesehatan di Jabodetabek dimana ekspektasi pemegang polis perusahaan asuransi kesehatan kesehatan di Jabodetabek kurang dari persepsi yang mereka terima.

\section{TINJAUAN PUSTAKA}

Perkembangan usaha bisnis pada masa kini semakin berkembang dengan pesat, hal ini bisa dilihat dari semakin tingginya tingkat persaingan antara perusahaan. Akibatnya perusahaan asuransi kesehatan pada umumnya berusaha untuk mempertahankan kelangsungan hidupnya untuk memperkuat posisi perusahaan dalam menghadapi perusahaan pesaing. Kunci utama kesuksesan suatu perusahaan yaitu fungsi perusahaan asuransi kesehatan yang sesuai dengan harapan pemegang polisnya. Selain itu perusahaan asuransi kesehatan pastinya juga berharap bisa memberikan produk yang bisa memuaskan konsumennya, sebab kepuasan konsumen menjadi tolak ukur dari berhasil atau tidaknya perusahaan dalam menghasilkan produk yang berkualitas dan yang diinginkan oleh konsumen. Artinya konsumen bukan sekedar membeli produk atau barangnya saja, tapi yang mereka cari dan beli adalah manfaat atau kegunaan dari sebuah produk. Dapat kita simpulkan bahwa kepuasan merupakan faktor kunci bagi konsumen dalam melakukan pembelian ulang, dimana hal ini merupakan porsi terbesar dari volume penjualan perusahaan. (Kotler \& Keller, 2016).

\section{Kualitas Pelayanan}

Sebelum menentukan konsep kualitas layanan akan lebih baik untuk menjelaskan sesuatu tentang layanan. Kini permasalahan tentang kualitas menjadi sesuatu yang harus diperhatikan oleh semua perusahaan jika perusahaan tersebut ingin tetap bertahan dalam bisnisnya. 
Definisi dari kata layanan adalah pekerjaan yang dilakukan oleh satu pihak ke pihak lainnya. (Perreault, 2003). Layanan adalah proses yang terdiri atas serangkaian kegiatan yang kurang lebih tidak berwujud yang secara alami (tapi tidak selalu) terjadi antara pemegang polis dan karyawannya atau penawaran layanan yang menjadi solusi untuk masalah pemegang polis. (Gronroos, 2000). Layanan adalah suatu aktivitas yang ditawarkan oleh satu pihak ke pihak lainya yang bersifat tidak berwujud tanpa kepemilikan. Hasilnya dapat menjadi produk nyata atau tidak nyata. (Kotler \& Armstrong, 2001).

Sedangkan kualitas berarti semua ciri-ciri maupun sifat dari sebuah produk atau pelayanan yang mempengaruhi kemampuan untuk memenuhi kebutuhan yang dinyatakan atau yang tersirat. (Kotler, 2015). Nilai yang diberikan oleh pemegang polis, didasari oleh faktor kualitas jasa. Melalui pengertian ini, dapat disimpulkan bahwa suatu barang atau jasa dapat dikatakan bermutu jika dapat memenuhi ekspektasi konsumen terhadap nilai produk yang diberikan kepada konsumen tersebut. Artinya, kualitas adalah salah satu faktor yang sangat menentukan diidalam penilaian tingkat kepuasan pelanggan.

Kualitas pelayanan berarti seberapa jauh perbedaan antara kenyataan dan harapan pemegang polis terhadap layanan yang mereka terima atau peroleh. (Mauludin, 2010). Kualitas pelayanan menjadi faktor yang sangat menentukan dalam menjaga keberlangsungan suatu perusahaan. Kualitas pelayanan yang baik, penting dalam mewujudkan kepuasan pelanggan.

\section{Model Servqual}

SERVQUAL merupakan sebuah model yang bisa digunakan untuk mengukur kualitas sebuah jasa. Model ini sekarang sangat populer dan yang paling banyak menjadi rujukan dalam riset manajemen dan juga pemasaran jasa (Tjiptono, 2005). Model ini pertama kali dikembangkan oleh A. Parasuraman, Valarie A. Zeithaml, dan Leonard L. Berry. Parasuraman et al. dalam Noufal et al., (2010) menyebutkan bahwa SERVQUAL merupakan metode yang dapat mengukur tingkat kepuasan pemegang polis terhadap layanan yang diberikan. Metode ini memperhatikan harapan pemegang polis mengenai layanan yang akan diterimanya (ekspektasi) dengan layanan yang telah diterimanya (persepsi).

Ada beberapa model yang bisa digunakan untuk menganalisis kualitas jasa, salah satunya adalah model GAP. Model ini merupakan tidak sesuainya antara layanan yang dirasakan (perceived service) dengan apa yang diharapkan (expected service). Ada lima GAP yang mengakibatkan gagalnya delivery suatu jasa yaitu :

a. Pertama, yaitu tidak sesuainya harapan konsumen dengan persepsi dari manajemen. Pada kenyataannya pihak manajemen dari suatu perusahaan tidak dapat selalu merasakan atau memahami apa yang diinginkan para pemegang polis secara tepat. Efeknya pihak manajemen tidak dapat mengetahui bagaimana suatu jasa seharusnya didesain, dan jasa-jasa pendukung /sekunder apa saja yang diharapkan oleh konsumen.

b. Kedua, yaitu tidak sesuainya persepsi manajemen dengan ekspektasi konsumen dan spesifikasi dari kualitas jasa. Tidak jarang sebuah perusahaan itu mengerti secara tepat apa yang diinginkan oleh pemegang polis, akan tetapi mereka belum menentukan standar kinerja tertentu dengan jelas. Penyebabnya ada tiga faktor, yaitu tidak adanya 
komitmen yang total dari manajemen terhadap kualitas jasa, kekurangan SDM, atau karena adanya request market yang overload.

c. Ketiga, yaitu tidak sesuainya spesifikasi dari kualitas jasa dengan kenyataan dilapangan. Ada beberapa penyebab terjadinya GAP ini, contohnya karyawan kurang terlatih beban kerja yang melampaui batas, karyawan tidak dapat memenuhi standar kinerja, atau bahkan tidak mau untuk memenuhi standar kinerja yang ditetapkan.

d. Keempat, yaitu tidak sesuainya penyampaian jasa dan komunikasi dengan konsumen. Konsumen itu ekspektasinya mudah sekali terpengaruh oleh TV commercial dan pernyataan atau janji yang diberikan oleh perusahaan. Resiko yang akan dihadapi perusahaan adalah jika janji yang sudah diberikan tidak sesuai kenyataan dilapangan.

e. Kelima, yaitu tidak sesuainya apa yang sebenarnya diharapkan oleh konsumen, dengan apa yang sebenarnya mereka dapat atau rasakan. Ketidaksesuaian ini terjadi dimana pemegang polis benar-benar mereview kinerja atau prestasi perusahaan dengan cara yang lain, atau bisa juga salah dalam berharap yang terlalu tinggi terhadap kualitas dari jasa tersebut.

\section{Membandingkan Model Kualitas Pelayanan}

Model dasar dari parasuraman et al (1985) telah mencakup sepuluh item. Namun para periset ini telah menemukan korelasi yang kuat antara komunikasi, kompetensi, kesopanan, kehandalan dan keamanan. Di sisi lain antara akses dan apperceive mereka juga telah menemukan korelasi yang kuat dalam ulasan mereka selanjutnya. Oleh karena itu, mereka menggabungkannya dalam dua dimensi keseluruhan seperti assurance dan empati. Dengan demikian mereka telah menciptakan lima dimensi seperti; Faktor tangible, reliability, responsiveness, Assurance dan Empathy sebagai alat dasar untuk mengevaluasi kualitas layanan. Skala ini memiliki lima dimensi dan 22 komponen sebagai sub dimensi untuk mengukur ekspektasi pemegang polis dan persepsi dimensi kualitas layanan. (Zeithaml \& Bitner, 1996, 152-153).

Dalam membandingkan model kualitas pelayanan, pertama responden akan diminta untuk memberi peringkat komponen model sesuai ekspektasi mereka terhadap layanan berdasarkan lima poin skala Likert. Selanjutnya responden yang sama akan diminta untuk menilai persepsi mereka tentang tindakan perusahaan yang sebenarnya sesuai dengan karakter yang sama. Frekuensi rata-rata setiap dimensi dihitung untuk semua responden. Namun, jika kinerja yang dirasakan di bawah dari harapan pemegang polis, maka kualitasnya buruk, dan jika kinerjanya lebih dari ekspektasi maka tingkat kualitas layanan pada penelitian ini berada pada tingkat tinggi.

\section{Dimensi Kualitas Pelayanan}

Dimensi SERVQUAL adalah suatu dimensi yang meliputi kualitas jasa dimana setiap jasa yang ditawarkan kepada konsumen mempunyai aspek-aspek yang bisa digunakan untuk mengetahui tingkat kualitasnya. Menurut teori Parasuraman yang dikutip oleh Tjiptono (2011:198) dimensi pelayanan jasa terdiri dari:

1. Bukti fisik (tangible), yaitu sejauh mana perusahaan mampu dalam menunjukan bukti eksistensi dirinya, contohnya meliputi fasilitas teknologi, penampilan dari 
karyawannya, dan hal lainya yanng menekankan secara bukti nyata fisik serta bisa diraba keberadaannya.

2. Keandalan (reliability), yaitu sejauh mana perusahaan dalam melayani apa yang sudah dijanjikan kepada pemegang polis. Contohnya bisa seperti melakukan perbaikan enhancement kinerja yang sesuai dengan ekspektasi dari pemegang polis.

3. Daya tanggap (responsiveness), yaitu seberapa cepatkah seroang agent atau karyawan dapat merespon kebutuhan dari konsumen. Contohnya perusahaan dan juga karyawan harus bisa memberikan service secara cepat dan tepat kepada pemegang polis saat mereka butuh bantuan.

4. Kepastian/ jaminan (assurance), yaitu bagaimana seorang karyawan dapat membuat konsumen merasa percaya dan juga yakin terhadap suatu porduk/ layanan dan juga kepada perusahaan tersebut. Unsur didalamnya seperti etika karyawan, kredibilitas karyawan, dan juga rasa aman dari pemegang polis.

5. Perhatian (emphaty), yaitu bagaimana caranya seorang karyawan bisa memberikan perhatian yang bersifat individu secara lebih dan juga tepat kepada seorang konsumen. Tujuanya adalah agar dari sisi perusahaan dapat memahami lebih dalam keinginan serta kebutuhan dari pemegang polisnya.

\section{Ekspektasi dan Persepsi Generasi Y}

Di zaman sekarang, setiap generasi pasti mempunyai ciri dan karakteristik yang berbeda, dan generasi yang paling menonjol adalah generasi Y. (Solomon, 2009). Ekspektasi bisa diartikan sebagai harapan kesenangan yang tidak konstan, yang timbul dari gagasan tentang sesuatu hal di masa depan. Pemegang polis tidak akan berhenti sampai proses evaluasi alternatif pasca konsumsi, di mana pemegang polis merasa puas atau tidak puas terhadap konsumsi produk atau jasa yang telah dilakukannya, hal ini sesuai dengan pemegang polis yang berharap tentang bagaimana produk dan kualitas yang sesungguhnya dirasakan pemegang polis. (Iskandar \& Bernarto, 2010). Memasuki era generasi Y, akan berdampak pada perubahan lingkungan di segala industri termasuk industri asuransi. Perubahan perilaku pemegang polis dari generasi $X$ ke generasi $Y$ akan membuat tantangan baru bagi industri asuransi berbagai negara. Di Indonesia sendiri, khususnya di Jabodetabek, kesadaran proteksi diri pada generasi $Y$ sudah mulai banyak namun masih rendah.

Lantas, bagaimanakah persepsi Gen $Y$ terkait perusahaan asuransi kesehatan? Dari landasan teori tersebut dapat kita asumsikan bahwa Generasi Y secara umum memiliki sudut pandang yang berbeda dengan generasi pendahulu, yaitu generasi Baby Boomer, yang cenderung memiliki persepsi negatif terhadap investasi seperti sebuah asuransi. Menurut OJK, pada tahun 2013 tercatat sebesar 17,84\% dari seluruh penduduk Indonesia yang memahami manfaat dari asuransi. Namun hanya sebesar $11,81 \%$ saja orang yang membeli polis, diantaranya berasal dari Generasi Y.

\section{Manfaat Kepuasan Pemegang Polis}

Walaupun setiap salesman sukses pasti selalu ingin memberikan layanan yang memuaskan pada pemegang polis, namun hal ini bukanlah satu-satunya tujuan dari marketing. Organisasi dan perusahaan tidak dapat mengabaikan tujuan utama mereka seperti 
mendapatkan keunggulan kompetitif melalui profit. Kepuasan pemegang polis memiliki kontribusi dalam mendapatkan banyak benefit untuk perusahaan asuransi kesehatan dan juga tingkat kepuasan pemegang polis yang besar memberikan kontribusi kepada pemegang polis loyalty (Mehrdad Asghari \& Dr. S. Harish Babu, 2017) .

\section{Kepuasan Pemegang Polis dan Kualitas Layanan}

Konsep Kualitas Pelayanan dan Kepuasan Pemegang polis mendapatkan perhatian lebih selama masa dekade lalu di dalam buku-buku dan seminar pemasaran. Para peneliti marketing menjunjung tinggi manfaat dari kualitas pelayanan dan tingkat kepuasan. Mereka menyebutnya sebagai indikator dari competitive advantage, meskipun sifat dasar dari pemegang polis judgement dan hubungan antara konsep kualitas pelayanan dan kepuasan pemegang polis diragukan (Ruyter, dkk, 1997, 388).

Pengaruh antara dimensi kualitas pelayanan terhadap penciptaan kepuasaan maupun ketidakpuasaan tidak memiliki dimensi yang berbeda. Dua kata ini (Kepuasan dan Ketidakpuasan), ibaratnya adalah seperti dua sisi koin (Parasuraman, dkk, 1998). Silvesteri \& Johnston (1990) memperkenalkan tiga jenis faktor seperti; Faktor higiene (Unsatisfied Factor), Enhancing (Satisfied Factor) dan faktor keduanya/ Dualthreshold Factor (Unsatisfied dan Satisfied Factor) yang dikutip dalam Health and Motivational Factor oleh Herzberg. Berdasarkan pendapat mereka, Unsatisfied factor adalah faktor dimana di saat mereka ada, faktor ini akan membawa pemegang polis merasa tidak puas, meskipun tanpa adanya faktorfaktor ini tidak mengakibatkan adanya kepuasan.

\section{METODOLOGI PENELITIAN}

Mengacu pada jurnal rujukan kami mengenai Understanding of Customer Expectations and Perceptions of Indian Health Insurance Companies oleh Mehrdad Asghari dan Dr. S. Harish Babu penelitian ini merupakan penelitian kuantitaif yang bersifat deskripsi, yaitu penelitian yang menggambarkan fenomena sosial, menyajikan gambaran yang spesifik dari sebuah situasi, biasanya menggunakan teknik pengumpulan data berupa survei, dan hasil yang ditunjukkan berupa presentase (Neuman, 2000).

Penelitian ini menggunakan data primer dan data sekunder. Berdasarkan literatur rujukan yang ada, teknik pengumpulan data menggunakan metode survei dan menggunakan alat ukur yakni SERVQUAL MODEL yang di-modify oleh Parasuraman, Zenithaml dan Berry (1985) untuk mengevaluasi hubungan antara kualitas pelayanan asuransi dan kepuasan pemegang polis (pemegang polis asuransi kesehatan). Skala SERVQUAL meliputi lima dimensi kualitas jasa yaitu tangibles (bukti fisik), reliability (reabilitas), responsiveness daya tanggap), assurance (jaminan), dan empathy (empati).

Metode penelitian ini sesuai dengan jurnal rujukan yakni menggunakan metode SERVQUAL yang digunakan untuk mengevaluasi kualitas dari layanan yang diberikan oleh perusahaan asuransi kesehatan pada generasi Y. Kualitas dari layanan termasuk pada perbedaan (gap) yang terjadi di antara persepsi pemegang polis dari perusahaan asuransi kesehatan dan ekspektasi dari pelayanan yang diterima. Dimana setiap dimensi memiliki beberapa pertanyaan dan dijawab dalam rentang nilai 1 sampai 5, di mana angka 1 mewakili 
perasaan sangat tidak setuju (strongly disagree) dan angka 5 mewakili perasaan sangat setuju (strongly agree), dengan total pertanyaan sebanyak 22.

Pertanyaan pada setiap bagian kami berikan sesuai dengan jurnal rujukan yang kita modifikasi agar lebih memudahkan responden. Dimana pada bagian yang pertama kuisioner merupakan filter pertama pada responden yang menanyakan apakah memiliki atau tidaknya asuransi. Pada bagian kedua kuisioner merupakan filter kedua pada responden yang menanyakan berapakah umur dari responden. Pada bagian ketiga merupakan filter ketiga yang menanyakan dimanakah domisili dari responden. Pada bagian keempat merupakan 22 pernyataan untuk mengevaluasi ekspektasi pemegang polis kesehatan berdasarkan 5-point skala Likert. Pada bagian kelima merupakan 22 pernyataan untuk mengevaluasi persepsi pemegang polis kesehatan berdasarkan 5-point skala Likert. Pada bagian kelima merupakan spesifikasi demografi bagi para responden, yakni : jenis kelamin, tingkat Pendidikan akhir, pengeluaran per bulan, dan status pernikahan. Karakteristik demografi dari responden pada penelitian ini tertuang dalam tabel 1.

Tabel 1 Demografi Responden

\begin{tabular}{|c|c|c|c|}
\hline \multicolumn{2}{|r|}{ Deskripsi } & Frekuensi & Persentasi \\
\hline \multirow{2}{*}{$\begin{array}{c}\text { Jenis } \\
\text { Kelamin }\end{array}$} & Laki-laki & 91 & $66 \%$ \\
\hline & Perempuan & 46 & $34 \%$ \\
\hline \multirow{6}{*}{ Umur } & Di bawah 17 tahun & 0 & $0 \%$ \\
\hline & $17-21$ & 1 & $1 \%$ \\
\hline & $22-26$ & 48 & $35 \%$ \\
\hline & $27-31$ & 63 & $46 \%$ \\
\hline & $32-37$ & 25 & $18 \%$ \\
\hline & Di atas 37 tahun & 0 & $0 \%$ \\
\hline \multirow{7}{*}{$\begin{array}{l}\text { Tingkat } \\
\text { Pendidikan } \\
\text { Terakhir }\end{array}$} & Di bawah SMP & 0 & $0 \%$ \\
\hline & SMP & 0 & $0 \%$ \\
\hline & SMA / SMK & 5 & $4 \%$ \\
\hline & D1 / D3 & 8 & $6 \%$ \\
\hline & S1 & 110 & $80 \%$ \\
\hline & S2 & 14 & $10 \%$ \\
\hline & S3 & 0 & $0 \%$ \\
\hline \multirow{7}{*}{$\begin{array}{c}\text { Pengeluaran } \\
\text { per bulan }\end{array}$} & Kurang dari Rp 500,000 & 0 & $0 \%$ \\
\hline & Rp 500,001 - Rp 700,000 & 5 & $4 \%$ \\
\hline & $\operatorname{Rp} 700,001-\operatorname{Rp~1,000,000~}$ & 2 & $1 \%$ \\
\hline & $\operatorname{Rp~1,000,001~-~Rp~1,500,000~}$ & 7 & $5 \%$ \\
\hline & $\operatorname{Rp} 1,500,001-\operatorname{Rp} 2,000,000$ & 11 & $8 \%$ \\
\hline & $\operatorname{Rp} 2,000,001-\operatorname{Rp} 3,000,000$ & 23 & $17 \%$ \\
\hline & Lebih dari Rp 3,000,000 & 89 & $65 \%$ \\
\hline \multirow{2}{*}{$\begin{array}{c}\text { Status } \\
\text { Pernikahan }\end{array}$} & Belum menikah & 98 & $72 \%$ \\
\hline & Menikah & 39 & $28 \%$ \\
\hline
\end{tabular}


Populasi dari penelitian ini adalah seluruh pemilik polis kesehatan asuransi yang berdomisili di Jabodetabek. Namun untuk sampel dari penelitian ini adalah generasi $Y$ yang memiliki polis asuransi kesehatan yang berdomisili di wilayah Jabodetabek. Dimana generasi $Y$ adalah laki-laki dan perempuan yang memiliki rentang umur antara 17 tahun - 37 tahun. Sample dari penelitian ini berjumlah 138 orang terdiri dari laki-laki sebanyak 92 orang dan perempuan sebanyak 46 orang.

Data yang telah dikumpulkan diolah menggunakan statistik deskriptif via SPS dan Excel tools seperti : testing reliability, mean, standard deviation, dan paired sample t-test untuk mengevaluasi adanya kesenjangan antara ekspektasi pemegang polis dengan persepsi mereka.

\section{ANALISIS DATA}

Sebelum kita memproses dari data primer, terlebih dahulu kita menghitung Alpha Cronbarch's dari kuisioner yang telah kita sebarkan untuk menguji reliability dari kuisioner tersebut, yakni dengan hasil sebagai berikut:

Tabel 2 Alpha Cronbach's

\begin{tabular}{|c|c|c|c|}
\hline \multicolumn{4}{|c|}{ Alpha Cronbach's } \\
\hline \multirow{5}{*}{ kspektasi } & Reliabilitas & 0.827 & \multirow{5}{*}{0.941} \\
\hline & Jaminan & 0.800 & \\
\hline & Bukti Fisik & 0.713 & \\
\hline & Empati & 0.819 & \\
\hline & Daya Tangkap & 0.889 & \\
\hline \multirow{5}{*}{ Persepsi } & Reabilitas & 0.889 & \multirow{5}{*}{0.970} \\
\hline & Jaminan & 0.833 & \\
\hline & Bukti Fisik & 0.843 & \\
\hline & Empati & 0.937 & \\
\hline & Daya Tangkap & 0.934 & \\
\hline
\end{tabular}

Dari tabel di atas bisa dilihat bahwa nilai Alpha Cronbach's adalah sebesar 94,1\% untuk ekspektasi dan $97 \%$ untuk persepsi yang artinya bahwa kuisioner yang telah peneliti sebar sudah melebihi dari batas minimal yakni $60 \%$ sehingga mampu menjelaskan konsep dari reliability dalam penelitian ini.

Tabel 3 Paired Sample T-test untuk semua kualitas layanan pada tiap dimensi

\begin{tabular}{|l|c|c|c|}
\hline \multicolumn{1}{|c|}{ Parameter } & Ekspektasi & Persepsi & Gap \\
\hline Reliabilitas & 4.472 & 3.936 & 0.536 \\
\hline Jaminan & 4.465 & 3.998 & 0.467 \\
\hline Bukti Fisik & 4.299 & 3.909 & 0.391 \\
\hline Empati & 4.473 & 4.013 & 0.460 \\
\hline Daya Tangkap & 4.400 & 3.787 & 0.613 \\
\hline
\end{tabular}




\begin{tabular}{|l|l|l|l|}
\hline Total & 22.108 & 19.642 & 2.466 \\
\hline
\end{tabular}

Tabel di atas merupakan hasil dari penelitian ini, di mana pada kolom Gap terlihat bahwa semua bernilai positif, yang artinya ekspektasi dari pemegang polis lebih besar dari persepsi mereka sendiri. Sehingga kita bisa menilai bahwa untuk saat ini kualitas layanan dari perusahaan asuransi kesehatan untuk polis kesehatan di Jabodetabek masih berada di bawah persepsi para pemegang polis pemegang polis terutama pada gen Y. Dengan kata lain bahwa perusahaan asuransi kesehatan masih belum memberikan kepuasan bagi para pemegang polis pemiliki polis kesehatan mereka.

\section{KESIMPULAN}

Setelah melakukan evaluasi terhadap kualitas layanan dari perusahaan asuransi kesehatan di Jabodetabek, data yang ditunjukkan melalui tabel sebelumnya memberikan gambaran adanya gap antara ekspektasi pemegang polis generasi $Y$ di Jabodetabek dengan persepsi terhadap produk dan layanan oleh perusahaan asuransi kesehatan. Dimana para pemegang polis yakni para generasi $Y$ di Jabodetabek masih belum puas pada setiap parameter kualitas pelayanan asuransi kesehatan yang ada.

Saran untuk industri asuransi kesehatan, dari penelitian ini menunjukkan bahwa perusahaan asuransi kesehatan sebaiknya lebih peka terhadap poin-poin dari kualitas layanan yang perusahaan tawarkan untuk seluruh parameter kualitas layanan melalui sudut pandang pemegang polis. Dan Perusahaan asuransi kesehatan harus mencoba untuk mengurangi gap ini dan di tahap berikutnya harus mengambil tindakan untuk memperbaiki gap dan berusaha untuk menawarkan layanan yang melebihi ekspektasi pemegang polis.

Hasil yang peneliti dapatkan memberikan gambaran adanya gap antara ekspektasi pemegang polis generasi $Y$ di Jabodetabek dengan persepsi terhadap produk dan layanan oleh perusahaan asuransi kesehatan. Oleh karena itu untuk penelitian selanjutnya diharapkan peneliti dapat menurunkan nilai gap ini (2.5) dan juga menemukan faktor mana yang paling mempengaruhi yang dapat menurunkan gap antara ekspektasi pemegang polis generasi $Y$ di Jabodetabek dengan persepsi terhadap produk dan layanan oleh perusahaan asuransi kesehatan.

\section{REFERENSI}

Asghari M. dan Babu Harish S. (2017), "Understanding of Customer Expectations and Perceptions of Indian Health Insurance Companies", International Journal of Engineering Trends and Technology (IJETT), 43, No. 3 (January):138 - 146

Kotler and Amstrong. (2001), Prinsip-prinsip pemasaran, Edisi keduabelas, Jilid 1. Erlangga, Jakarta

Kotler et.al. (2015), Marketing, Pearson HigherEducation AU, London

Kotler, Philip and Kevin Lane Keller. (2016), Marketing Management, 15th Edition, Pearson Education, Inc, London 
McCarthy et.al. (2003), Dasar-dasar Pemasaran, Edisi kelima, alih Bahasa : Agus Darma. Erlangga, Jakarta

Gronroos and Christian. (2000), Service Management and Marketing: A Moment of Truth, Maxwell Macmillan International, Singapore

Scaning Business Environment and Tools, http://blog.stie-mce.ac.id, (18 Agustus 2017)

Iskandar, A. dan I. Bernarto. (2010), "Pengaruh Kualitas Pelayanan Restoran Platinum Lippo Karawaci Terhadap Loyalitas Pelanggan: Kepuasan Pelanggan Sebagai Variabel Intervening", DeReMa Jurnal Manajemen 2.(2)143-160

Solomon, M.R. and Rabolt,N. (2009), Consumer Behavior in Fashion, 2nd Edition. Prentice Hall, USA

Atkinson, R. L., Atkinson, R. C., Smith, E. E. (2008), “Pengantar Psikologi jilid 2 ed: 11". Interaksara, Jakarta

Boeree, G. (2005), Personality Thories, Prismasophie, Yogyakarta

Nirwana, (2004), Prinsip-prinsip Pemasaran Jasa. Dioma, Malang

Parasuraman, A., Zeithaml, V. A., \& Berry, L. L. (1985), “A conceptual model of service quality and its implications for future research", Journal of Marketing, No. 41-50

Parasuraman, A., Zeithaml, V. A., \& Berry, L. L.(1988), "SERVQUAL: a multiple-item scale for measuring consumer perceptions of service quality", Journal of Retailing Vol. 64 No. 1: $12-40$

Grönroos, C. (2007), Service management and marketing: customer management in service competition, John Wiley \& Sons, California

Situs Wikipedia, http://www.wikipedia.com (27 Juli 2017)

Ghobadian, A., Speller, S., \& Jones, M. (1994), "Service quality: concepts and models", International journal of quality \& reliability management, No.11(9): 43-66

Situs Jakarta Consulting, http://www.jakartaconsulting.com/publications/articles/corporate-culture/generasi-y, (4 Juli 2017)

Mannheim, Karl. (1923), "The Problem of Generations", The Problem with Generations Essays on the Sociology of Knowledge, London

Zeitaml, Berry dan Parasuraman (dalam Tjiptono dan Chandra, 2011), Service Quality.

Zeithaml, Valerie, A., and Bitner, Mary Jo, 1996, Service Marketing, McGrow Hill, Singapore

Cronin, J. J., Brady, M. K., Brand, R. R., Hightower Jr, R., \& Shemwell, D. J. (1997), “A crosssectional test of the effect and conceptualization of service value", Journal of services Marketing, No.11(6): 375-391

Johnston, R., Silvestro, R., Fitzgerald, L., \& Voss, C. (1990), "Developing the determinants of service quality", in The Proceedings of the 1st International Research Seminar, in Service Management La Londes les Maures, United Kingdom

Herzberg, Frederick. (1993), "Motivation to Work", Health and Motivational Factor, John Wiley \& Sons, New York. 


\section{LAMPIRAN}

Hasil penelitian dari data yang peneliti olah melalui survey, dapat dijabarkan sebagai berikut :

\begin{tabular}{|c|c|c|c|c|c|c|c|c|c|}
\hline \multirow{2}{*}{ No } & \multirow{2}{*}{ Parameter } & \multirow{2}{*}{ Pertanyaan } & \multicolumn{2}{|c|}{ Ekspetasi (E) } & \multicolumn{2}{|c|}{ Persepsi (P) } & \multirow{2}{*}{$\begin{array}{c}\text { Gap } \\
(\mathrm{E}-\mathrm{P}) \\
\text { Mean }\end{array}$} & \multirow[t]{2}{*}{$\begin{array}{c}\text { t- } \\
\text { value }\end{array}$} & \multirow[t]{2}{*}{$\begin{array}{l}\text { Sig. (2- } \\
\text { Tailed) }\end{array}$} \\
\hline & & & Mean & $\begin{array}{l}\text { Std. } \\
\text { Dev }\end{array}$ & Mean & $\begin{array}{l}\text { Std. } \\
\text { Dev }\end{array}$ & & & \\
\hline 1 & \multirow{3}{*}{ Realibilitas } & $\begin{array}{l}\text { Perusahaan } \\
\text { asuransi } \\
\text { kesehatan yang } \\
\text { baik } \\
\text { menjanjikan } \\
\text { untuk } \\
\text { melakukan } \\
\text { sesuatu pada } \\
\text { jangka waktu } \\
\text { tertentu dan } \\
\text { menepatinya. }\end{array}$ & 4.336 & 0.788 & 3.956 & 0.726 & 0.380 & 4.284 & 0.000 \\
\hline 2 & & $\begin{array}{l}\text { Perusahaan } \\
\text { asuransi } \\
\text { kesehatan yang } \\
\text { baik adalah } \\
\text { perusahaan } \\
\text { yang simpatik } \\
\text { (peduli) dan } \\
\text { memberikan } \\
\text { rasa aman } \\
\text { dalam } \\
\text { perlindungan }\end{array}$ & 4.526 & 0.516 & 3.920 & 0.697 & 0.606 & 8.780 & 0.000 \\
\hline 3 & & $\begin{array}{l}\text { Perusahaan } \\
\text { asuransi } \\
\text { kesehatan yang } \\
\text { baik adalah } \\
\text { perusahaan } \\
\text { yang dapat } \\
\text { diandalkan }\end{array}$ & 4.547 & 0.528 & 3.869 & 0.765 & 0.679 & 9.006 & 0.000 \\
\hline
\end{tabular}




\begin{tabular}{|c|c|c|c|c|c|c|c|c|c|}
\hline 4 & & $\begin{array}{l}\text { Perusahaan } \\
\text { asuransi } \\
\text { kesehatan yang } \\
\text { baik adalah } \\
\text { perusahaan } \\
\text { yang } \\
\text { menyediakan } \\
\text { layanan sesuai } \\
\text { pada saat yang } \\
\text { dibutuhkan }\end{array}$ & 4.453 & 0.641 & 3.876 & 0.771 & 0.577 & 6.972 & 0.000 \\
\hline 5 & & $\begin{array}{l}\text { Perusahaan } \\
\text { asuransi } \\
\text { kesehatan yang } \\
\text { baik adalah } \\
\text { perusahaan } \\
\text { yang mencatat } \\
\text { data pemegang } \\
\text { polis secara } \\
\text { akurat }\end{array}$ & 4.496 & 0.570 & 4.058 & 0.673 & 0.438 & 6.613 & 0.000 \\
\hline 6 & Jaminan & $\begin{array}{l}\text { Perusahaan } \\
\text { asuransi } \\
\text { kesehatan yang } \\
\text { baik adalah } \\
\text { perusahaan } \\
\text { yang membuat } \\
\text { anda merasa } \\
\text { aman saat } \\
\text { bertransaksi } \\
\text { dengan agen } \\
\text { asuransi } \\
\text { tersebut }\end{array}$ & 4.518 & 0.544 & 4.000 & 0.717 & 0.518 & 7.448 & 0.000 \\
\hline 7 & & $\begin{array}{l}\text { Perusahaan } \\
\text { asuransi } \\
\text { kesehatan yang } \\
\text { baik adalah } \\
\text { perusahaan } \\
\text { yang memiliki }\end{array}$ & 4.540 & 0.515 & 4.051 & 0.721 & 0.489 & 7.027 & 0.000 \\
\hline
\end{tabular}




\begin{tabular}{|c|c|c|c|c|c|c|c|c|c|}
\hline & & $\begin{array}{l}\text { agen asuransi } \\
\text { bersikap sopan }\end{array}$ & & & & & & & \\
\hline 8 & & $\begin{array}{l}\text { Perusahaan } \\
\text { asuransi } \\
\text { kesehatan yang } \\
\text { baik adalah } \\
\text { perusahaan } \\
\text { yang } \\
\text { memberikan } \\
\text { agen asuransi } \\
\text { fasilitas yang } \\
\text { memadai untuk } \\
\text { melakukan } \\
\text { pekerjaan } \\
\text { mereka dengan } \\
\text { baik }\end{array}$ & 4.336 & 0.645 & 3.942 & 0.725 & 0.394 & 5.113 & 0.000 \\
\hline 9 & Bukti Fisik & $\begin{array}{l}\text { Perusahaan } \\
\text { asuransi } \\
\text { kesehatan yang } \\
\text { baik adalah } \\
\text { perusahaan } \\
\text { yang } \\
\text { memberikan } \\
\text { layanan secara } \\
\text { modern yang } \\
\text { memudahkan } \\
\text { transaksi dan } \\
\text { informasi }\end{array}$ & 4.562 & 0.554 & 3.978 & 0.742 & 0.584 & 7.556 & 0.000 \\
\hline 10 & & $\begin{array}{l}\text { Perusahaan } \\
\text { asuransi } \\
\text { kesehatan yang } \\
\text { baik adalah } \\
\text { perusahaan } \\
\text { yang } \\
\text { memberikan } \\
\text { fasilitas yang } \\
\text { menarik bagi }\end{array}$ & 4.409 & 0.536 & 3.723 & 0.855 & 0.686 & 7.987 & 0.000 \\
\hline
\end{tabular}




\begin{tabular}{|c|c|c|c|c|c|c|c|c|c|}
\hline & & anda & & & & & & & \\
\hline 11 & & $\begin{array}{l}\text { Perusahaan } \\
\text { asuransi } \\
\text { kesehatan yang } \\
\text { baik adalah } \\
\text { perusahaan } \\
\text { yang memiliki } \\
\text { agen asuransi } \\
\text { berpenampilan } \\
\text { rapih }\end{array}$ & 4.124 & 0.712 & 4.029 & 0.606 & 0.095 & 1.310 & 0.000 \\
\hline 12 & & $\begin{array}{l}\text { Perusahaan } \\
\text { asuransi } \\
\text { kesehatan yang } \\
\text { baik adalah } \\
\text { perusahaan } \\
\text { yang } \\
\text { memberikan } \\
\text { materi yang } \\
\text { berhubungan } \\
\text { dengan layanan } \\
\text { dengan } \\
\text { tampilan yang } \\
\text { menarik }\end{array}$ & 4.102 & 0.572 & 3.905 & 0.674 & 0.197 & 2.873 & 0.000 \\
\hline 13 & $S$ & $\begin{array}{l}\text { Perusahaan } \\
\text { asuransi } \\
\text { kesehatan yang } \\
\text { baik adalah } \\
\text { perusahaan } \\
\text { yang } \\
\text { memberikan } \\
\text { perhatian } \\
\text { secara personal } \\
\text { pada anda }\end{array}$ & 4.299 & 0.623 & 3.788 & 0.878 & 0.511 & 5.975 & 0.000 \\
\hline 14 & & $\begin{array}{l}\text { Perusahaan } \\
\text { asuransi } \\
\text { kesehatan yang } \\
\text { baik adalah }\end{array}$ & 4.153 & 0.674 & 3.650 & 0.952 & 0.504 & 6.024 & 0.000 \\
\hline
\end{tabular}




\begin{tabular}{|c|c|c|c|c|c|c|c|c|}
\hline & $\begin{array}{l}\text { perusahaan } \\
\text { yang memiliki } \\
\text { agen asuransi } \\
\text { memberikan } \\
\text { perhatian } \\
\text { secara personal } \\
\text { pada anda. }\end{array}$ & & & & & & & \\
\hline 15 & $\begin{array}{l}\text { Perusahaan } \\
\text { asuransi } \\
\text { kesehatan yang } \\
\text { baik adalah } \\
\text { perusahaan } \\
\text { yang memiliki } \\
\text { agen asuransi } \\
\text { yang mengerti } \\
\text { apa yang anda } \\
\text { butuhkan }\end{array}$ & 4.358 & 0.591 & 3.701 & 0.869 & 0.657 & 7.899 & 0.000 \\
\hline 16 & $\begin{array}{l}\text { Perusahaan } \\
\text { asuransi } \\
\text { kesehatan yang } \\
\text { baik adalah } \\
\text { perusahaan } \\
\text { yang } \\
\text { memahami } \\
\text { keinginan anda } \\
\text { secara } \\
\text { sungguh- } \\
\text { sungguh. }\end{array}$ & 4.336 & 0.559 & 3.686 & 0.905 & 0.650 & 7.571 & 0.000 \\
\hline 17 & $\begin{array}{l}\text { Perusahaan } \\
\text { asuransi } \\
\text { kesehatan yang } \\
\text { baik adalah } \\
\text { perusahaan } \\
\text { yang memiliki } \\
\text { jam } \\
\text { operasional } \\
\text { yang sesuai }\end{array}$ & 4.182 & 0.678 & 3.737 & 0.868 & 0.445 & 5.253 & 0.000 \\
\hline
\end{tabular}




\begin{tabular}{|c|c|c|c|c|c|c|c|c|c|}
\hline & & $\begin{array}{l}\text { dengan } \\
\text { kebutuhan } \\
\text { anda }\end{array}$ & & & & & & & \\
\hline 18 & \multirow{3}{*}{$\begin{array}{l}\text { Daya } \\
\text { Tangkap }\end{array}$} & $\begin{array}{l}\text { Perusahaan } \\
\text { asuransi } \\
\text { kesehatan yang } \\
\text { baik adalah } \\
\text { perusahaan } \\
\text { yang } \\
\text { memberikan } \\
\text { informasi } \\
\text { secara tepat } \\
\text { kapan layanan } \\
\text { akan } \\
\text { direalisasikan }\end{array}$ & 4.401 & 0.535 & 3.854 & 0.772 & 0.547 & 7.127 & 0.000 \\
\hline 19 & & $\begin{array}{l}\text { Perusahaan } \\
\text { asuransi } \\
\text { kesehatan yang } \\
\text { baik adalah } \\
\text { perusahaan } \\
\text { yang memiliki } \\
\text { agen asuransi } \\
\text { yang } \\
\text { memberikan } \\
\text { layanan secara } \\
\text { cepat untuk } \\
\text { anda }\end{array}$ & 4.423 & 0.552 & 3.796 & 0.876 & 0.628 & 7.347 & 0.000 \\
\hline 20 & & $\begin{array}{l}\text { Perusahaan } \\
\text { asuransi } \\
\text { kesehatan yang } \\
\text { baik adalah } \\
\text { perusahaan } \\
\text { yang memiliki } \\
\text { agen asuransi } \\
\text { yang selalu } \\
\text { proaktif dalam } \\
\text { membantu }\end{array}$ & 4.350 & 0.625 & 3.701 & 0.918 & 0.650 & 6.858 & 0.000 \\
\hline
\end{tabular}




\begin{tabular}{|l|l|l|l|l|l|l|l|l|}
\hline & anda & & & & & & & \\
\hline & $\begin{array}{l}\text { Perusahaan } \\
\text { asuransi } \\
\text { kesehatan yang } \\
\text { baik adalah } \\
\text { perusahaan } \\
\text { yang memiliki } \\
\text { agen asuransi } \\
\text { yang selalu } \\
\text { memberikan } \\
\text { waktunya } \\
\text { untuk } \\
\text { merespon anda } \\
\text { secara cepat }\end{array}$ & 4.328 & 0.595 & 3.730 & 0.870 & 0.599 & 7.252 & 0.000 \\
\hline & $\begin{array}{l}\text { Perusahaan } \\
\text { asuransi } \\
\text { kesehatan yang } \\
\text { baik adalah } \\
\text { perusahaan } \\
\text { yang memiliki } \\
\text { agen asuransi } \\
\text { yang dapat } \\
\text { anda percaya }\end{array}$ & 4.496 & 0.502 & 3.854 & 0.879 & 0.642 & 7.124 & 0.000 \\
\hline
\end{tabular}

Table 4.2 Paired Sample T-test dan Evaluation Mode 